\title{
Neural signatures: multiple coding in spiking-bursting cells
}

\author{
Roberto Latorre - Francisco B. Rodríguez • \\ Pablo Varona
}

Published online: 23 January 2007

(C) Springer-Verlag 2006

\section{Erratum to: Biol Cybern 95:169-183}

\section{DOI 10.1007/s00422-006-0077-5}

The original publication was printed with the following errors:

Table 3: column 3 (Burst duration):

Values $53.5( \pm 0.7)$ and $53.7( \pm 0.5)$

should be $63.5( \pm 0.7)$ and $63.7( \pm 0.5)$, respectively.

Table 5: column 1, line labeled with (c):

It should be 'Signature reader CPG'

instead of 'Signature emitter CPG'.

The authors apologize for these typos.

The online version of the original article can be found at http://dx.doi.org/10.1007/s00422-006-0077-5.

R. Latorre $(\bowtie) \cdot$ F. B. Rodríguez · P. Varona

Grupo de Neurocomputación Biológica (GNB),

Departamento de Ingeniería Informática,

Escuela Politécnica Superior,

Universidad Autónoma de Madrid,

28049 Madrid, Spain

e-mail: Roberto.Latorre@uam.es

F. B. Rodríguez

e-mail: F.Rodriguez@uam.es

P. Varona

e-mail: Pablo.Varona@uam.es 